\title{
Economic and Environmental Performances of Organic Farming System Compared to Conventional Farming System: A Case Farm Model to Simulate the Horticultural Sector of the Niayes Region in Senegal
}

\author{
Amadou Binta $\mathrm{BA}^{1^{*}}$ and Bruno Barbier ${ }^{2}$ \\ ${ }^{1}$ Department of Economics and Management Sciences (FASEG), University Cheikh Anta Diop of Dakar, Dakar, Senegal \\ ${ }^{2}$ CIRAD UMR G-Eau (International Cooperation Center for Agronomic Research and Development), University Cheikh Anta Diop of Dakar, Dakar, Senegal
}

"Corresponding author: Amadou Binta BA, Department of Economics and Management Sciences (FASEG), University Cheikh Anta Diop of Dakar, Dakar, Senegal, Tel: 00221781715674; E-mail: mamyba2002@yahoo.fr; bbarbier@cirad.fr

Rec date: Apr 07, 2015; Acc date: June 24, 2015; Pub date: June 27, 2015

Copyright: (c) 2015 Amadou Binta BA, et al. This is an open-access article distributed under the terms of the Creative Commons Attribution License, which permits unrestricted use, distribution, and reproduction in any medium, provided the original author and source are credited.

\begin{abstract}
Horticultural production is an increasingly important activity in Senegal that is mainly located in the Niayes region between Dakar and St Louis. However, the increasing use of pesticides and inorganic fertilizers has many implications for the environment. The recognition that conventional horticulture might have a negative impact on farmers and consumers health, and on the atmosphere through the emission of GHGs, has increased in recent years, leading some NGO's to promote organic farming. Therefore, the rising level of environmental hazards from conventional farming system made it attractive to farmers in the Niayes to adopt sustainable agriculture practices based on organic farming.
\end{abstract}

A whole farm model is used to compare the economic and environmental performances of the organic and conventional horticultural farming systems in the Niayes region in Senegal. The gross margin is regarded as the economic indicator, while carbon emissions are regarded as environmental indicators. The results indicate that the conventional farming system is still more attractive than the organic farming because the sale price is the same for both systems. There is no market for organic food in the region. Simulation results also reveal that there exists a "win-win" situation for conventional farmers when they partially adopt organic farming system. However, environmental results in terms of carbon emissions reduction suggest that the organic system is more effective in mitigating climate change.

Our study suggests that, through appropriate investment in agro-ecological research to improve organic management and the establishment of a local market for organic crops, organic farming can become a competitive alternative to conventional farming, when it comes to healthy food production with less environmental impact in the horticultural sector. However, further studies are needed on components of sustainable intensification to see which system of production is more profitable for farmers of the Niayes region, but also beneficial for the environment, and at regional and even national levels.

Keywords: Organic farming; Conventional farming; Mathematical programming; Carbon emissions; Niayes

\section{Introduction}

The impact of agriculture on greenhouse gas emissions and climate change is important. Agriculture is a cause and victim of climate change. Also the agricultural sector is still the most important economic sector in many African countries, the one employing most people and the one where poverty prevails. Climate is one of the main determinants of agricultural productivity and climate change is expected to influence crop and livestock production [1]. The majority of households in developing countries depend on agriculture for their livelihoods and this dependency on agriculture make them more vulnerable to the effects of climate change [2].

In Senegal, the livelihoods of about $77 \%$ of the population depend on small-scale agriculture, which is adversely affected by the consequences of climate change. During the next decades, billions of people, particularly those in developing countries, will face changes in rainfall patterns that will contribute to severe water shortages or flooding, and raising temperatures that will cause shift in crop growing seasons [3]. While there is a growing concern about the impact of climate changes on agriculture, another ongoing process in agriculture is its contribution to climate change.

Modern industrial agriculture of the Green Revolution contributes to a great deal to climate change [4]. According to the Intergovernmental Panel on Climate Change [3], global warming causing climate change is due to anthropogenic greenhouse gases (GHGs), which include hydrofluocarbons $\left(\mathrm{CO}_{2}\right)$, perfluocarbons $\left(\mathrm{CH}_{2}\right)$, and sulphur hexafluoride $\left(\mathrm{N}^{2} \mathrm{O}\right)$ In fact, agriculture, which is our primary source of food, has contributed to the increase in greenhouse gas emissions through activities such as rice production, the use of synthetic fertilizers, livestock rearing, the change in land use patterns like deforestation [5]. The sector is said to be the main contributor to $\left(\mathrm{CH}_{4}\right)$ and $\left(\mathrm{N}_{2} \mathrm{O}\right)$ emissions $(60$ percent and 50 percent respectively), and also to a lesser extent to $\mathrm{CO}^{2}$ [6]. According to a report by FAO [7], agriculture causes approximately one-third of global GHGs, when direct energy use, emissions from livestock, the 
production of fertilizers, pesticides, machinery and equipment as well as soil degradation and land-use changes for feed production are taken into account.

Agriculture is part of the problem, but it is also considered to be part of the solution to mitigate climate change through agricultural practices that are climate resilient and environmentally friendly [8]. Recently, numerous reports have emphasized the need to proceed to major changes in the global food system: agriculture must meet the twin challenge of feeding a growing population with rising demand for meat and high-calories diets, while simultaneously minimizing its global environmental impacts $[9,10]$. The increasing population coupled with urbanization has serious implications for sustainable development in less favourable areas of developing countries. In addition, rapidly changing consumption patterns and the impact of climate change and environmental degradation are driving limited resources of food, energy, water and materials towards critical thresholds worldwide. Consequently, these pressures are likely to be substantial across Africa, where countries will have to find innovative ways to boost crop and livestock production to avoid becoming more reliant on import and food aid [11]. Furthermore, there is a need to search for solutions for climate change.

In the agricultural sector, which both emits and sequesters Greenhouse Gases (GHGs), the importance of mitigating the effects of GHG emissions is becoming increasingly significant [7]. Further, there is a growing consensus on the need to proceed to greater changes in agriculture and food systems so the world can feed itself, today and in the future, with healthy and nutritionally-high quality food, while contributing to fight poverty, preserving biodiversity and natural resources, mitigating and adapting to climate change in a resourceconstrained world [12].

In Senegal the National Adaptation Programme of Action (NAPA) was developed in 2006, following the recommendation to leastdeveloped countries to create policy frameworks that enable them to communicate more clearly about their vulnerabilities and priorities for adaption. This was followed by many other private and public interventions aiming at improving the livelihoods of vulnerable people through the introduction of various technologies for improving productivity, adapting and mitigating climate change. Among those technologies, organic farming techniques are gaining importance with the help of non-governmental organizations.

In the Niayes region, ENDA-PRONAT is one of the leading NGO's that have been promoting organic farming methods since 1986. Since, gardeners of the Niayes have started to gradually adopt organic farming techniques. Reports of the NGO's have shown that farmers who adopted these farming methods make a significant saving on the purchase of fertilizers and have improved their incomes, in addition to the positive environmental effects this method of farming offers. Studies on organic farming methods around the world reveal that they can increase agricultural productivity and can raise income with lowcost, locally available and appropriate technologies, without causing environmental damage (UNEP-UNCTAD, 2008). Organic agriculture is thus promoted to create an integrated, human, environmentally and economically viable agriculture system.

Organic agriculture is a production system that works entirely without synthetic fertilizers and pesticides based on practices which promote and enhance agro-ecosystem health, while conventional agriculture is a production system based on practices such as the use of synthetic fertilizers and pesticides. Many studies reveal that organic yields are lower than conventional yields [13-15]. Nonetheless most of those yield results are contextual and depend on many factors [13]. In contrast, numerous other studies have attempted to show that best practice organic agriculture can achieve comparable yields to conventional agriculture [16-21].

Many other studies such as the one of Nemes [22] concluded that, in general, organic farming is more profitable than the conventional farming system. Nemes [22] argued that, for a better analysis of the profitability of organic farming, one must go beyond balance sheets. Environmental, health and social dimensions must be therefore taken into consideration in the analysis. So there is a heated debate on the profitability of organic and conventional farming systems.

The present study will contribute to the debate by investigating the economic and environmental performances of the horticultural organic and conventional farming systems in two rural communities of the Niayes region in Senegal. The results will, therefore, not only give more insights into the debate by providing empirical evidence and further will help policy makers in designing strategies for climate change mitigation and adaptation and for rural livelihood improvement in Senegal.

The paper is structured into four sections. The first section has already provided the background information and context of the study. The following section describes the data collection and methodological procedure. Section III presents results and discussion. Section IV discusses the conclusion and policy recommendations.

\section{Materials and Methods}

\section{Data collection procedures}

Semi-structured questionnaires were used to collect primary data on organic and conventional farming practices. We used a random sampling technique for the selection of conventional farmers and purposively selected organic farmers with the help of the leading NGO of organic farming in the study area. A sample of 40 farmers was selected consisting of 20 each from conventional and organic farms in two rural communities of the Niayes zone in Senegal (Keur Moussa and the Diender) in 2014. A farm of 1.5 ha from each system (organic and conventional) was selected as a representative farm of family farmers in the study area to apply linear programming approach that reflects the situation of organic and conventional farming systems. The 1.5 ha is the average size of the land under exploitation by the respondents in the study area.

Data was also collected through semi-structured interviews with experts, heads of farmers' organisations and focus group discussions. In addition, we gathered information from national structures, international institutions, NGO's (such as Enda Pronat) and local associations. These include the following: in Keur Moussa, "la fédération des agriculteurs de Keur Moussa" (Woobin) and in Diender, "la fédération des Agropasteurs de Diender" (FAPD). We have observed that many farmers are not adopting 100\% organic practices because they are doing it progressively, but for our study we only considered those that have totally adopted the system. Our questionnaire was improved by the mean of pre-testing that has been done one week before the data collection.

From the organic farming system, we found a number of farming practices such as crop rotation, green manuring, use of cover crops, application of animal and compost manures and the use of natural pest 
Citation: Amadou Binta BA, Barbier B (2015) Economic and Environmental Performances of Organic Farming System Compared to Conventional Farming System: A Case Farm Model to Simulate the Horticultural Sector of the Niayes Region in Senegal. J Horticulture

control, mainly from "Nime" trees and a bio-pesticide named bio-beat . "Nime" extract from trees is the product mostly used by organic farmers because of its availability throughout the country. The second mostly used is the bio-beat, which is a biological product formulated commercially by the agrochemical industry and is easily accessible to farmers. However, there exist other sources of natural pest control such as botanical extracts from pepper, tomato and tobacco leaves which are not very popular and are a bit costly.

The main problems faced by organic farmers in the study area are: the availability of organic inputs such as cow manures, poultry manures and composts, the maturation time of organic crops are longer compared to conventional crops, pest attacks from neighbouring conventional farms, lack of good quality seeds and the non-existence of a local market for organic products. Animal manures and compost are essential components for organic farming. However, livestock farming is not very developed in the Niayes. Therefore, organic farmers often have to buy animal manures from non-local livestock owners. All these constraints limit the amount of land they are able to cultivate.

On the other hand, the conventional system is characterised by practices like the use of chemical fertilizers (urea and NPK), the use of chemical pesticides, crop rotation and, to some extent, the application of poultry and cow manures. The main problems facing conventional farmers in the study area are: lack of good quality seeds, the lack of conservation units for crop products in case they are not sold and, sometimes, the non-availability of inputs such as fertilizers and pesticides at the right moment.

The problem of lack of financial means due to difficulties to access to credit is common for both systems. In Diender, farmers use water from wells for irrigation, while in Keur Moussa farmers mostly use water corporations for irrigation, which is very costly. So water availability is a limiting factor for farmers in the Keur Moussa zone.

\section{Methodology}

Mathematical programming (MP) models are optimization models widely used for analysis in agriculture and economics. Buysse et al. [23] justified the motivation for using programming models in agricultural economics in that the fundamental economic problem is how to make the best use of limited resources. A mathematical programming model from an analytical perspective tries to identify an extreme (i.e., minimum or maximum) point of a function $\mathrm{f}(\mathrm{X} 1, \mathrm{X} 2$, $\ldots, \mathrm{Xn})$, that satisfies a set of constraints such as $\mathrm{g}(\mathrm{X} 1, \mathrm{X} 2, \ldots, \mathrm{Xn}) \leq \mathrm{b}$ [24]. So, mathematical programming models offer great possibilities to formulate a wider range of actual and potential activities and to determine their relative attractiveness.

There exists a wider range of different mathematical programming, from disaggregate single farm optimization models to highly aggregated sectoral models [25]. Mathematical models can take many forms, including but not limiting to dynamic systems, statistical models, differential equations or game theory models [26]. Following Hazell and Norton (1986), a typical mathematical programming model is written in the following form:

$$
\begin{aligned}
& \operatorname{Max} Z=\sum_{i=1}^{n} C_{i} X_{i} \\
& \text { St } \sum_{i=1}^{n} A_{j i} X_{i} \leq B j \text { all } j=1 \ldots m \\
& \text { And } X_{i} \geq 0 \text { for all } i=1 \ldots n
\end{aligned}
$$

Where $\mathrm{Z}$ is called the objective function, $\mathrm{X}$ is the vector of decision variables and $B$ is the vector of available resources. The problem is to maximize the value of the objective functions according to the fulfillment of the resources' constraints and the no-negativity requirement. The models have been applied to solve different problems and aim at providing recommendations about the most efficient or economically rewarding way to run the agricultural activity.

The basic model: In order to analyse the economic and environmental attractiveness of organic farming system, a linear programming model is developed for a representative farm from each system (conventional and organic) in the Niayes region of Senegal. Linear programming is said to be one of the strong and most suitable techniques to analyse and compare the results in different production practices. Our basic model is as follows:

$$
\begin{aligned}
& \operatorname{Max} \mathrm{Z}=\sum_{\mathrm{j}}^{\mathrm{n}} \mathrm{Y}_{\mathrm{j}} \mathrm{P}_{\mathrm{j}}-\sum_{\mathrm{f}=1}^{\mathrm{D}} \sum_{\mathrm{j}=1}^{\mathrm{n}} \mathrm{P}_{\mathrm{fj}} \mathrm{Q}_{\mathrm{fj}} \sum_{\mathrm{m}=1}^{\mathrm{H}} \sum_{\mathrm{j}=1}^{\mathrm{n}} \mathrm{P}_{\mathrm{mj}} \mathrm{Q}_{\mathrm{mj}}{ }^{-} \sum_{\mathrm{p}=1}^{\mathrm{V}} \sum_{\mathrm{j}=1}^{\mathrm{n}} \mathrm{P}_{\mathrm{pj}} \mathrm{Q} \\
& \sum_{\mathrm{s}=1}^{\mathrm{B}} \sum_{\mathrm{j}=1}^{\mathrm{n}} \mathrm{P}_{\mathrm{sj}} \mathrm{Q}_{\mathrm{sj}}-\left(\sum_{\mathrm{l}=1}^{\mathrm{R}} \sum_{\mathrm{j}=1}^{\mathrm{n}} \mathrm{W}_{\mathrm{lj}} \mathrm{N}_{\mathrm{j}} \mathrm{D}_{\mathrm{lj}}+\sum_{\mathrm{l}}^{\mathrm{R}} \sum_{\mathrm{j}}^{\mathrm{n}} \mathrm{S}_{\mathrm{lj}} \mathrm{N}_{\mathrm{j}} \mathrm{T}_{\mathrm{j}}\right)-\mathrm{c}_{\mathrm{j}} \mathrm{W}
\end{aligned}
$$

(1)

\section{Subject to:}

$\sum_{\mathrm{t}}^{\mathrm{E}} \sum_{\mathrm{j}=1}^{\mathrm{n}} \mathrm{L}_{\mathrm{tj}} \mathrm{X}_{\mathrm{j}} \mathrm{L}_{\mathrm{j}} \leq L$ (Labour Constraint)(2) $\sum_{\mathrm{j}=1}^{\mathrm{n}} \mathrm{L}_{\mathrm{j}} \mathrm{X}_{\mathrm{j}} \leq \mathrm{L}$ (Land Constraint) (3) $\sum_{j=1}^{n} W_{j} X_{j} \leq W$ (Water Constraint)(4) $\sum_{j=1}^{n} K_{j} X_{j} \leq K$ (Capital Constraint)(5) $\sum_{\mathrm{j}=1}^{\mathrm{n}} \mathrm{Q}_{\mathrm{fj}} \mathrm{X}_{\mathrm{J}} \leq \mathrm{Q}_{\mathrm{fr}} \quad$ (Fertilizer Constraint)(6) $\sum_{\mathrm{j}=1}^{\mathrm{n}} \mathrm{Q}_{\mathrm{fj}} \mathrm{C}_{\mathrm{j}} \mathrm{X}_{\mathrm{j}} \leq \mathrm{Q}_{\mathrm{cr}} \quad$ (Carbon Constraint)(7) $X_{j} \geq 0 ; j=1 . . . \mathrm{n}$ NonNegativity $(8)$

$\mathrm{Z}$ refers to the objective function (gross margin) in which net income from various crop productions in monetary term is maximized.

$Y_{j}=$ Yield per hectare of the $j^{\text {th }}$ activity;

$\mathrm{P}_{\mathrm{j}}=$ Price of crop $\mathrm{j}$

$\mathrm{J}=$ crop activities (tomato, onion, eggplant, cabbage and green pepper)

$P_{f j}=$ Price of fertilizer used for the $j_{\text {th }}$ activity

$\mathrm{Q}_{\mathrm{f}}=$ Quantity of fertilizer used for the $\mathrm{j}^{\text {th }}$ activity

$\mathrm{Q}_{\mathrm{fr}}=\mathrm{Quantity}$ of fertilizer recommended for one hectare

$\mathrm{P}_{\mathrm{mj}}=$ Price of manure used for the $\mathrm{j}^{\text {th }}$ activity

$Q_{m j}=Q$ uantity of manure used for the $j^{\text {th }}$ activity

$P_{p j}=$ Price of pesticides used for the $j^{\text {th }}$ activity

$Q_{p j}=Q$ uantity of pesticides used for the $j^{\text {th }}$ activity

$\mathrm{C}_{\mathrm{j}}=$ Carbon equivalent for the $\mathrm{j}^{\text {th }}$ activity

$\mathrm{Q}_{\mathrm{fj}}=\mathrm{Quantity}$ of fertilizer used for the $\mathrm{j}^{\mathrm{th}}$ activity

$\mathrm{Q}_{\mathrm{cr}}=$ Quantity of carbon emissions recommended

$\mathrm{W}_{\mathrm{lj}}=$ Daily labour wage for temporary workers used for the $\mathrm{j}^{\text {th }}$ activity

$\mathrm{N}_{\mathrm{j}}=$ Number of temporary workers used for the $\mathrm{j}^{\text {th }}$ activity

$D_{1 j}=$ Number of temporary labour days used for the $j^{\text {th }}$ activity

$\mathrm{S}_{\mathrm{lj}}=$ Monthly salary for seasonal workers used for the $\mathrm{j}^{\text {th }}$ activity 
$\mathrm{N}_{\mathrm{j}}=$ Number of seasonal workers used for the $\mathrm{j}^{\text {th }}$ activity

$\mathrm{T}_{\mathrm{j}}=$ Number of months per season used for the $\mathrm{j}^{\text {th }}$ activity

$c_{j}=$ Price of water used for the $j^{\text {th }}$ activity

$\mathrm{W}=\mathrm{Quantity}$ of water used for the $\mathrm{j}^{\mathrm{th}}$ activity

$\mathrm{X}_{\mathrm{j}}=$ Level of the $\mathrm{j}^{\text {th }}$ activity in hectares (ha)

$\mathrm{L}_{\mathrm{j}}=$ Land needed for the $\mathrm{j}^{\mathrm{th}}$ activity

$\mathrm{L}=$ Total land available to farmer

$\mathrm{K}_{\mathrm{j}}$ Capital (cash) needed for the the $\mathrm{j}^{\text {th }}$ activity

$\mathrm{K}=$ Total available cash capital

$\mathrm{W}_{\mathrm{j}}=$ Water needed for the $\mathrm{j}^{\text {th }}$ activity ;

$\mathrm{W}=$ Total available water

$\mathrm{L}_{\mathrm{tj}}=$ Number of labour man-days required per hectare by crop $j$ during period $\mathrm{t}$.

Our basic model consists of a whole-farm linear programme for a representative farm of each agricultural system (conventional and organic) which is made up of the objective function and constraints. Thus, at first the model seeks to capture the main farm activities, which are primarily vegetables production. So in the first instance, the mathematical programming model is used to obtain the optimal farm plan of each of the farm types. This will be derived from gross margin maximisation that is assumed to be the objective of the farmers and is used to measure the economic performances of the farms. Then, the optimal farm plan is estimated across increasing levels of carbon emission reduction to measure the environmental performances of the two systems of production.

The maximization problem is estimated through linear programming by using the General Algebraic Modeling System (GAMS). Per hectare costs per season in conventional and organic farming systems are estimated by including cash costs (costs of seed, fertilizer, pesticide, manure, hired labour and other operations, such as the cost of irrigation). Non cash-costs, such as family labour costs, are not included in the analysis under the assumption that family labour is surplus and has no opportunity costs. The revenue is estimated by multiplying the total production after deduction of the quantity consumed at home with the market price of the product. The gross margin is then calculated as the financial output revenue minus the total costs. The gross margin is expressed in CFAF. The base model is also altered to analyse the sensitivity of the results to changes in prices of labour, vegetable crops and labour and land use change.

Crops enterprises: Several types of vegetable crops can be grown on the sample farm in the Niayes zone. Four crops that dominate the production system of family farming in the study area are included in the model. These are tomato, onion, eggplant, cabbage and green pepper. The farm is divided into plots so that all the crops can be grown every season. In the objective function, the net revenue from crops is included by multiplying total harvest per hectare by average market price. The average market prices vary according to each season, as well crop yield per hectare also can vary in response to climate change. The market price is higher in the rainy season, lower in cold season and in-between in the intermediate season.

Labour constraints: Two types of labour are used and are designated family labour and hired labour. Under each category of labour available, labour allocation is based on the labour requirement of each enterprise during each stage of the agricultural activities. Field operations (land preparation, transplanting/sowing, crop care, hand weeding, water spray and harvesting) have to be performed during a particular period of the season throughout the year. Therefore, the year is divided into seasons lasting 4 months maximum each. The working days are considered to be 25 days (Sunday is a day off) per month and $8 \mathrm{hr}$ a day (from $7 \mathrm{am}$ to $12 \mathrm{am}$ in the morning and $3 \mathrm{pm}$ to $6 \mathrm{pm}$ in the afternoon).

In our representative farms, three types of labour are used to perform the different tasks. These are family labour, contract labour/ permanent workers and temporary hired labour (only at picking periods such as harvesting). In the two rural communities (Diender and Keur Moussa) the majority of contract or permanent workers make arrangements with the owner of the farm to share a portion of yield after harvest. However, in some farms (mainly conventional) we found the requirement of two contract or permanent workers with monthly wages of 25000 FCFAF per month for each worker and an additional charge related to the cost of feeding them estimated about 30,000 FCFAF per month

Temporary hired labour varies according to the period, for harvesting the cost is about 1500 FCFA per day/worker. For other operations such as transplanting, hand weeding and land preparation the cost is about 1000 FCFA per day/worker. The number of temporary workers varies also according to the types of crop and tasks. Labour restrictions are measured in man-hours and the restraint levels are determined from the size and composition of permanent workers, average temporary workers and family labour supply per month.

Land constraint: We have two types of farming systems in the study area; industrial and family farming systems. The average cultivated land allocated for the production of crops varies according to the farming types. The average arable land under exploitation by farmers is used as the upper limit of land constraints. The farms analyzed are typical family farming of the south and centre zones of the Niayes. In this region, the average farm size for family farming is about 1.5 ha. In our analysis, the size and soil type of the sample farm is therefore 1.5 ha and clay-sandy soil, respectively. Farmers divide their land into several portions, growing various vegetables allowing crop rotation and ensuring a constant supply of fresh vegetables as they mature at different times.

Capital constraint: Working capital is a factor of production consisting of the costs of seed and fertilizer, hired labour costs and transportation costs, etc. This capital is one of the constraints limiting the production level of farmers. The amount of capital a farmer could invest for vegetable production in a year is considered to be the total operating capital available to that farmer.

Rotation constraint: Both organic and conventional farmers in the study area are practicing mixed farming. The farm is divided into portions of land allowing the cultivation of a variety of crops each season except for the rainy season. In the rainy season there is a high risk of yield lost because of pest diseases and flooding risk. The rotation constraint is based on dividing the farm into parts, and then rotating the crops within each part in such a way so that the total acreage of each crop grown on the farm is about constant each season.

Fertilizer constraint: Fertilizers play an important role in increasing production and the use of the resource is constrained by its high price. The major types of fertilizer considered in the study are urea and NPK for the conventional farm, and poultry manure, cow manure and compost in the organic farm. 
Citation: Amadou Binta BA, Barbier B (2015) Economic and Environmental Performances of Organic Farming System Compared to Conventional Farming System: A Case Farm Model to Simulate the Horticultural Sector of the Niayes Region in Senegal. J Horticulture

Page 5 of 10

Carbon constraint: Carbon emissions are regarded in the model as an environmental factor. To analyse the environmental performances of the two systems we set a constraint on carbon emissions and develop a scenario which reduces progressively carbon emissions as a policy to mitigate climate change. To get the carbon emission equivalent, we considered the nitrogen contained in each type of fertilizer or pesticides and then use the IPCC (2007) greenhouse emissions carbon equivalent to calculate the carbon equivalent in each system according to the amount of fertilizer and pesticides used.

\section{Results and Discussions}

\section{Survey results}

The findings of the survey and farm observation reveal that the mean age of farmers surveyed was about 46 years in the organic system, while in the conventional system it was about 45 years. Gender analysis show that there were more females involved in organic farming than in conventional farming (out of 20 farmers interviewed in the organic system 9 were female and out of 20 farmers interviewed in the conventional system only 5 were female). The average farmers were married and the family members (head of household, spouse and children) were the source of family labour. The different crops produced by farmers were cabbage, tomato, eggplant, onion, bitter eggplant, cucumber, zucchini, parsley and green onion. The average farm size under exploitation was about 1.6 ha in the conventional system and 1.4 ha in the organic system. Therefore we use 1.5 ha as an upper bound for land constraint in the simulation analysis.

Resources use and cropping activities: This section includes observed data which are grouped into three categories; namely cultivated area, cropping activities and labour requirement.

Average land area under cultivation for each crop in both systems: The average land area under exploitation of each system is used for various crops during a year. The land area (ha) used to grow various crops from both systems in the study area is presented in table 1. It was found that the land area under cultivation for each crop was greater in the conventional farm compared to the organic farm. According to organic farmers, because of the high risk and the non-existence of a local organic market they cannot cultivate a big portion of the available land.

\begin{tabular}{|l|l|l|}
\hline Crops & Conventional farm & Organic farm \\
\hline Cabbage & 0.62 & 0.41 \\
\hline Eggplant & 0.38 & 0.24 \\
\hline Green pepper & 0.4 & 0.27 \\
\hline Tomato & 0.37 & 0.27 \\
\hline Onion & 0.67 & 0.41 \\
\hline
\end{tabular}

Table 1: Average cultivated area (ha) for various crops in different farms at the study area.

Crop activities: Cropping activities include growing a different cropping cycle in successive season during a year. Outlines of the most commonly used cropping cycles in the two systems at the study sites in the Niayes in a year is presented in Table 2.
Labour requirement: Labour requirement for different crops depend on the crop type and farming system. It was observed that the organic farm rely more on family labour compared to the conventional farm (Table 3).

\begin{tabular}{|l|l|l|}
\hline Rainy Season & Cold Season & Dry Season \\
\hline Cabbage & Cabbage & Cabbage \\
\hline Eggplant & Eggplant & Eggplant \\
\hline Green pepper & Green pepper & Green pepper \\
\hline & Onion & Tomato \\
\hline & Tomato & \\
\hline
\end{tabular}

Table 2: Cropping cycle.

\begin{tabular}{|l|l|l|l|l|}
\hline Crops & \multicolumn{2}{l|}{ Conventional Farm } & \multicolumn{2}{l|}{ Organic Farm } \\
\hline & Hired labour & $\begin{array}{l}\text { Family } \\
\text { labour }\end{array}$ & Hired labour & $\begin{array}{l}\text { Family } \\
\text { labour }\end{array}$ \\
\hline Cabbage & 200 & 32 & 216 & 40 \\
\hline Eggplant & 216 & 32 & 184 & 40 \\
\hline Green pepper & 216 & 20 & 184 & 30 \\
\hline Onion & 240 & 32 & 240 & 40 \\
\hline Tomato & 200 & 20 & 216 & 30 \\
\hline
\end{tabular}

Table 3: Labour required (man/hours) in the production of different crops in the two systems.

Economics of crop production: The gross margin of each crop for each system is presented in the following Tables 4, 5 and 6. In addition, we present in Table 7 the gross margin of organic crops with a premium price. We present in these Tables the yield, price, and cost of cultivation, revenues per hectare and the gross margin for each crop per hectare. It was not an easy task to determine reliable costs of production (factor input costs such as land and labour, non-factor input costs such as fertilizers, manure, seed, pesticides, organic pesticides, irrigation, etc.). In spite of some difficulties, we had enough reliable data to perform the comparison of the two systems of production. As it can be seen in the tables the gross margin of conventional crops is higher than organic crops. However, when a premium price is applied to organic crops the situation is reversed. Thus, conventional farmers of the vegetable sector of the Niayes region have higher revenues compared to organic vegetable farmers due to the non-existence of a local market for organic products and to the lower yield observed in the organic farm.

Analysis of yield per hectare: The graph indicates that yields of the four crops onion, green pepper, cabbage, eggplant and tomato are higher on the conventional farm. There is no big difference between the two systems in term of yield in terms of the yield of onion. The yield of cabbage is very high in the conventional farm compared to the rest of the three other crops (Figure 1). 
Citation: Amadou Binta BA, Barbier B (2015) Economic and Environmental Performances of Organic Farming System Compared to Conventional Farming System: A Case Farm Model to Simulate the Horticultural Sector of the Niayes Region in Senegal. J Horticulture 2: 152. doi:10.4172/2376-0354.1000152

Page 6 of 10

\begin{tabular}{|c|c|c|c|c|c|c|c|c|c|c|c|c|c|c|c|}
\hline \multirow{2}{*}{ CROPS } & \multicolumn{3}{|c|}{ Yields In Ha } & \multicolumn{3}{|c|}{ Prices In Cfa } & \multicolumn{3}{|c|}{ Revenues In Cfa } & \multicolumn{3}{|c|}{ Costs In Cfa } & \multicolumn{3}{|c|}{ Gross Margin In Cfa } \\
\hline & T1 & T2 & T3 & T1 & $\mathrm{T} 2$ & T3 & T1 & T2 & T3 & T1 & T2 & T3 & T1 & T2 & T3 \\
\hline Onion & 11000 & 11000 & 0 & 125 & 150 & 200 & 1375000 & 1650000 & 0 & 779750 & 779750 & 0 & 595250 & 870250 & 0 \\
\hline $\begin{array}{l}\text { Green } \\
\text { pepper }\end{array}$ & 10798 & 10798 & 8000 & 300 & 500 & 800 & 3239400 & 5399000 & 6400000 & 843750 & 843750 & 843750 & 2515650 & 4675250 & 5656250 \\
\hline Cabbage & 14720 & 14720 & 10720 & 100 & 150 & 300 & 1472000 & 2208000 & 3216000 & 877750 & 877750 & 87775 & 594250 & 1330250 & 2338250 \\
\hline Eggplant & 10782 & 10782 & 6382 & 75 & 109 & 200 & 808650 & 1175238 & 2156400 & 630250 & 630250 & 630250 & 178400 & 544988 & 1526150 \\
\hline Tomato & 8782 & 8782 & 0 & 300 & 344 & 375 & 2634600 & 3021008 & 0 & 599750 & 599750 & 0 & 2034850 & 2421258 & 0 \\
\hline
\end{tabular}

Table 4: Average yields, revenue per ha for different conventional crops for different seasons.

\begin{tabular}{|c|c|c|c|c|c|c|c|c|c|c|c|c|c|c|c|}
\hline \multirow{2}{*}{ CROPS } & \multicolumn{3}{|c|}{ Yiels In Ha } & \multicolumn{3}{|c|}{ Prices In Cfa } & \multicolumn{3}{|c|}{ Revenues In Cfa } & \multicolumn{3}{|c|}{ Costs In Cfa } & \multicolumn{3}{|c|}{ Gross Margin In Cfa } \\
\hline & $\mathrm{T} 1$ & T2 & T3 & $\mathrm{T} 1$ & $\mathrm{~T} 2$ & T3 & $\mathrm{T} 1$ & T2 & T3 & $\mathrm{T} 1$ & T2 & T3 & T1 & T2 & T3 \\
\hline Onion & 10280 & 10280 & 0 & 125 & 150 & 200 & 1285000 & 1541000 & 0 & 720000 & 720000 & 0 & 565000 & 822000 & 0 \\
\hline $\begin{array}{l}\text { Green } \\
\text { pepper }\end{array}$ & 8640 & 8640 & 5640 & 300 & 500 & 800 & 25292000 & 4320000 & 6912000 & 723500 & 723500 & 723500 & 1868500 & 359650 & 6189000 \\
\hline Cabbage & 11156 & 11156 & 8156 & 100 & 150 & 300 & 1115600 & 1673400 & 3904600 & 6463000 & 643000 & 643000 & 472600 & 1030400 & 1803800 \\
\hline Eggplant & 7980 & 7980 & 5890 & 75 & 109 & 200 & 598500 & 1197000 & 1178000 & 580500 & 580500 & 580500 & 18000 & 2892320 & 597500 \\
\hline Tomato & 5344 & 5344 & 0 & 300 & 344 & 375 & 1603200 & 1838336 & 0 & 575000 & 575000 & 0 & 1028200 & 11263336 & 0 \\
\hline
\end{tabular}

Table 5: Average yields, revenue per ha for different organic crops for different seasons.

\begin{tabular}{|c|c|c|c|c|c|c|c|c|c|c|c|c|c|c|c|}
\hline \multirow{2}{*}{ Crops } & \multicolumn{3}{|c|}{ Yields in ha } & \multicolumn{3}{|c|}{$\begin{array}{l}\text { Premium prices } \\
\text { in cfa }\end{array}$} & \multicolumn{3}{|c|}{ Revenues in cfa } & \multicolumn{3}{|c|}{ Costs in cfa } & \multicolumn{3}{|c|}{ Gross margin in cfa } \\
\hline & $\mathrm{T} 1$ & $\mathrm{~T} 2$ & T3 & $\mathrm{T} 1$ & $\mathrm{~T} 2$ & T3 & $\mathrm{T} 1$ & $\mathrm{~T} 2$ & T3 & T1 & $\mathrm{T} 2$ & T3 & $\mathrm{T} 1$ & $\mathrm{~T} 2$ & T3 \\
\hline Onion & 10280 & 10280 & 0 & 150 & 175 & 250 & 1542000 & 1799000 & 0 & 72000 & 72000 & 0 & 822000 & 1079000 & 0 \\
\hline Greenpeppefr & 8640 & 8640 & 5640 & 350 & 600 & 900 & 3024000 & 5184000 & 5076000 & 723500 & 723500 & 723500 & 2300000 & 4460500 & 4352500 \\
\hline Cabbage & 11156 & 11156 & 8156 & 150 & 200 & 350 & 1673400 & 2231200 & 39004600 & 643000 & 643000 & 643000 & 1030400 & 1588200 & 3261600 \\
\hline Eggplant & 7980 & 7980 & 5890 & 125 & 150 & 300 & 997500 & 1197000 & & 580500 & 580500 & 580500 & 417000 & 616500 & 1213500 \\
\hline Tomato & 5534 & 5534 & 0 & 350 & 400 & 500 & 1936900 & 2213600 & 0 & 575000 & 575000 & 0 & 1361900 & 1638600 & 0 \\
\hline
\end{tabular}

Table 6: Average yields, revenue and costs per ha for different organic crops for different seasons. Costs=cost of fertilizers+cost of pesticides+cost of labour+cost of irritation+other costs(machinery for plowing,transportation), Revenue=yield ${ }^{*}$ price ; Gross margin=revenue-cost, $\mathrm{T} 1=$ cold season; $\mathrm{T} 2=$ dry season; $\mathrm{T} 3=$ rainy season.

Environmental indicator analysis: Figure 2 below shows the $\mathrm{CO}_{2}$ emissions per crop of both systems. The carbon emissions are higher in the conventional system than in the organic system. The analysis per crop shows that the production of cabbages and eggplants has the highest level of carbon emissions of all of the crops. This is explained in that the production of cabbages and eggplants required a high level use of pesticides to fight of insects and worms.

\section{Simulation model results}

To compare the vegetable organic and conventional farming systems in the Niayes zone, economic and environmental simulation results are analysed and compared. The results are presented under four sub- headings, namely technical results, economic results, environmental results and sensitive analysis.

Technical results: The optimal farm plan for organic and conventional farming for the three seasons is presented in table 7. The results show that the gross margin is maximised by the combination of five crops, namely onion, green pepper, cabbage, eggplant and tomato. As it can be seen from the table below, the cropping cycle and the land area allocated to each crop vary according to the system of production. We have five planting months in the conventional farm (April, May, July, September, and December) and four planting months in the organic farm (April, May, September, and October). 
Citation: Amadou Binta BA, Barbier B (2015) Economic and Environmental Performances of Organic Farming System Compared to Conventional Farming System: A Case Farm Model to Simulate the Horticultural Sector of the Niayes Region in Senegal. J Horticulture

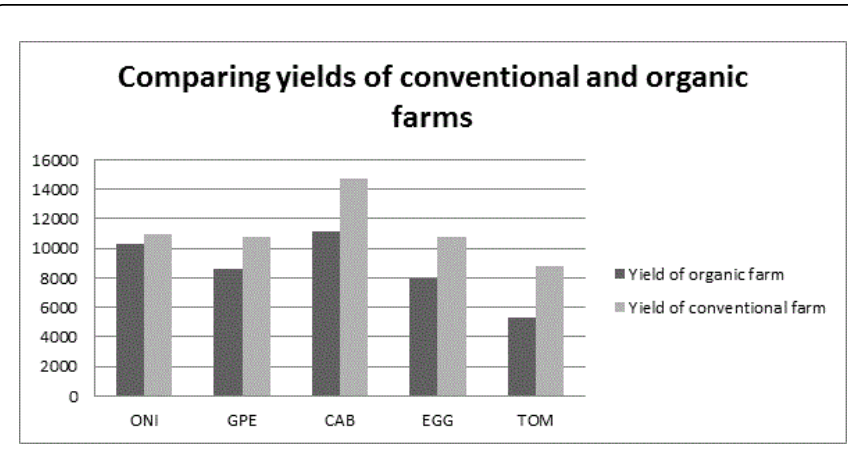

Figure 1: Comparing yields of conventional and organic farms.

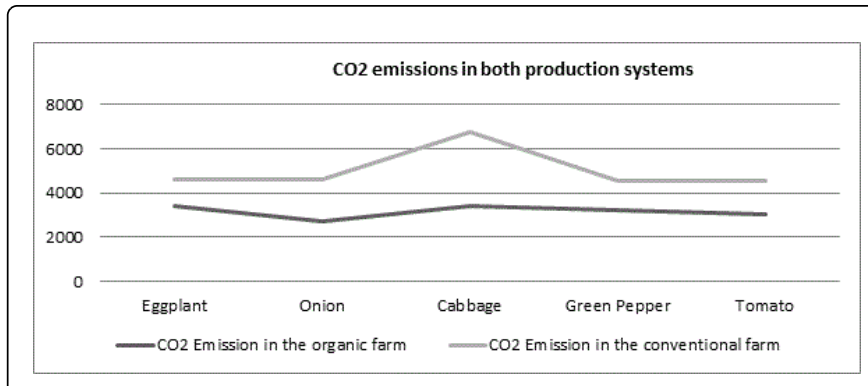

Figure 2: Comparison of carbon emissions in the two production systems.

\begin{tabular}{|c|c|c|c|c|c|c|c|c|c|}
\hline \multirow{2}{*}{ Crops } & \multicolumn{5}{|c|}{ Conventional system } & \multicolumn{4}{|c|}{ Organic system } \\
\hline & T4 & T5 & $\mathrm{T} 7$ & T9 & $\mathrm{T} 12$ & T4 & T5 & T9 & $\mathrm{T} 10$ \\
\hline Onion & & & & & 0.6 & & & & 0.4 \\
\hline Green pepper & & 0.6 & & & & & 0.4 & & \\
\hline Cabbage & 0.037 & 0.563 & & & & 0.4 & & & \\
\hline Eggplant & 0.072 & & 0.126 & & & 0.4 & & & \\
\hline Tomato & & & & 0.6 & & 0.057 & & 0.343 & \\
\hline Total area & 0.109 & 1.163 & 0.126 & 0.6 & 0.6 & 0.857 & 0.4 & 0.343 & 0.4 \\
\hline
\end{tabular}

Table 7: Optimal farm plan of the two systems in different cropping cycles.

Technical results for resource use in both systems of production are presented in appendices. The results show that land allocation is not fully used by all systems, but the conventional system has used slightly more land than the organic system. In contrast to many findings (Acs et al. 2006 ;), labour use is slightly greater in the conventional system compared to the organic system. This can be explained in that; there were more land use for cultivation in the conventional system. The quantity of water used for irrigation is slightly higher in the conventional farm compared to the organic farm. This is due to the fact that the system of production based on organic farming helps to retain soil moisture and humidity, because of the use of animal manures and composts as fertilizers, but also the practices of crop covering and inter-cropping. Carbon emissions are also higher in the conventional farm, but both systems are $\mathrm{CO}_{2}$ emitters (Table 8).

Economic results: The economic results of both farming systems are shown in the Table 8 .

\begin{tabular}{|l|l|l|l|}
\hline & Organic farm & Conventional farm & $\begin{array}{l}\text { Mix organic and } \\
\text { conventional farm }\end{array}$ \\
\hline $\begin{array}{l}\text { Gross } \\
\text { margin(CFA) }\end{array}$ & $4,431,600$ & $82,521,164$ & \\
\hline $\begin{array}{l}\text { Gross margin } \\
\text { with premium } \\
\text { prices }\end{array}$ & $61,112,137$ & & \\
\hline
\end{tabular}

\begin{tabular}{|l|l|l|l|}
\hline $\begin{array}{l}\text { Gross margin in a } \\
\text { "win-win" situation }\end{array}$ & & $10,407,870$ \\
\hline
\end{tabular}

Table 8: Annual gross margin in conventional and organic farming.

The gross margin of organic farming is less than the gross margin of conventional in both situations. However, when we perform the simulation with organic crops at a premium price, the organic farm is better off compared to a situation where there is no local market for organic crops. Further, when we allow the conventional farm to partially adopt organic farming, we get a better economic situation ('win-win' situation) for farmers. Therefore, conventional farming system seems to perform better economically than organic farming in vegetable production in the Niayes region. These findings are in contrast to findings from some studies carried out in European countries, the US and some African countries [21,27-32](Langley et al. 1983; Van Mansvelt and Mulder, 1993; Stockdale et al., 2001; Mahoney et al., 2004; Acs et al. 2006; Tanrivermiş H (2008); Delbridge et al. 2011; Delbridge et al., 2013; Ndungu et al. 2013) , conventional farming system seems to perform better economically than organic farming in vegetable production in the Niayes region.

Environmental results: The environmental performances of the two systems were analysed by applying an environmental regulation to carbon emissions in the model. Specifically, the regulation consists of reducing the level of carbon emissions progressively and observing its effect on the gross margin of each farm (organic and conventional) and 
Citation: Amadou Binta BA, Barbier B (2015) Economic and Environmental Performances of Organic Farming System Compared to Conventional Farming System: A Case Farm Model to Simulate the Horticultural Sector of the Niayes Region in Senegal. J Horticulture

Page 8 of 10

on the optimal farm plan as well. The results of the simulations are shown in the table 9 below.

\begin{tabular}{|c|c|c|c|c|}
\hline & \multicolumn{2}{|c|}{ Organic gross margin(CFA) } & \multicolumn{2}{|c|}{$\begin{array}{l}\text { Conventional } \\
\text { margin(CFA) }\end{array}$} \\
\hline & & $\begin{array}{lr}\text { Rate of } \\
\text { decrease (\%) }\end{array}$ & & $\begin{array}{lr}\text { Rate of } \\
\text { decrease (\%) }\end{array}$ \\
\hline Baseline & $4,431,600$ & & $8,252,164$ & \\
\hline $\begin{array}{l}10 \% \\
\text { decrease in } \\
\mathrm{CO}_{2}\end{array}$ & $4,431,600$ & & $8,252,164$ & \\
\hline $\begin{array}{l}20 \% \\
\text { decrease in } \\
\mathrm{CO}_{2}\end{array}$ & $4,431,600$ & & $8,227,186$ & 0.3 \\
\hline $\begin{array}{l}30 \% \\
\text { decrease in } \\
\mathrm{CO}_{2}\end{array}$ & $4,431,600$ & & $8,167,518$ & 1.03 \\
\hline $\begin{array}{l}40 \% \\
\text { decrease in } \\
\mathrm{CO}_{2}\end{array}$ & $4,431,600$ & & $8,106,774$ & 1.76 \\
\hline $\begin{array}{l}50 \% \\
\text { decrease in } \\
\mathrm{CO}_{2}\end{array}$ & $4,431,600$ & & $8,040,887$ & 2.56 \\
\hline $\begin{array}{l}60 \% \\
\text { decrease in } \\
\mathrm{CO}_{2}\end{array}$ & $4,431,600$ & & $7,363,196$ & 10.77 \\
\hline $\begin{array}{l}70 \% \\
\text { decrease in } \\
\mathrm{CO}_{2}\end{array}$ & $4,431,600$ & & $6,471,770$ & 21.57 \\
\hline $\begin{array}{l}80 \% \\
\text { decrease in } \\
\mathrm{CO}_{2}\end{array}$ & $4,085,161$ & 7.82 & $5,382,404$ & 34.77 \\
\hline $\begin{array}{l}90 \% \\
\text { decrease in } \\
\mathrm{CO}_{2}\end{array}$ & $2,888,985$ & 57.37 & $3,737,554$ & 54.7 \\
\hline
\end{tabular}

Table 9: Impact of a decrease in carbon emissions on the gross margin of each system.

As it can be seen from the table above, the conventional system is more sensitive to policies of carbon emission abatement. Up to a reduction of $80 \%$, there is no change in the gross margin of the organic farm, while for the conventional farm a reduction of $20 \%$ of carbon emissions led to a reduction of the gross margin of about $0.30 \%$.

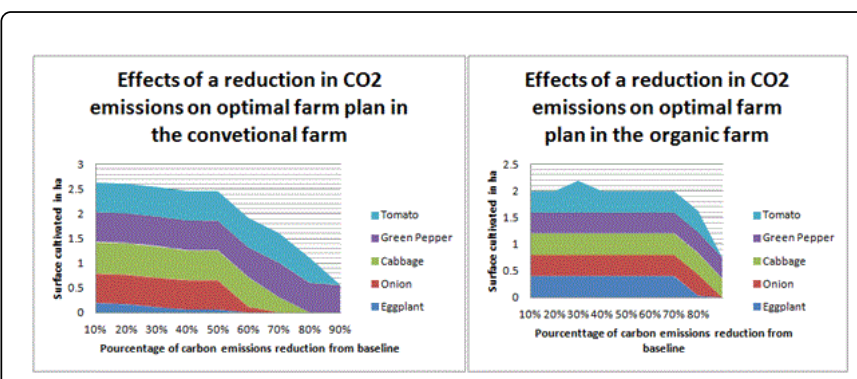

Figure 3: Effects of $\mathrm{CO}_{2}$ emissions reduction on the optimal farm plan.
As shown in the figure above, when we reduce progressively the level of carbon emissions in the model the conventional farm starts to reduce the area of land allocated to those crops that emit more carbon. From a threshold of $50 \%$ of reduction the conventional farm starts to abandon the cultivation of certain crops. Whereas, in the organic farm even a strong constraint on carbon emissions consisting of a reduction of $70 \%$ has no effect on the optimal farm plan. The environmental regulation starts to have an effect similar to that of conventional farm only from a reduction of $80 \%$. Thus, from this analysis, we can conclude that organic farming is better environmentally, when it comes to mitigating climate change. However, further environmental analyses are needed in order to get more insights into further issues such as carbon sequestration.

In summary, an environmental regulation that consists of a reduction in carbon emission will lead to a "Trade-off" situation where farmers have to abandon crops that requiremore inorganic fertilizers in favour of those crops that emit less carbon. Therefore, an environmental regulation which consists of reducing the emission of GHGs could be an effective tool for policy makers in encouraging farmers to adopt sustainable farming systems such as organic farming in the study area.

Sensitive analysis: Testing the sensitivity of the model to key parameters is important because it helps evaluate the robustness of the model.

In our model the two farms did not use all the land and all the water available, we focused on capital, labour and crop rotation. Also we tested the robustness of prices. Capital availability is a limiting factor in the conventional farm. An increase of the available capital by one unit will increase the gross margin of the farm by 1.5. Capital is not a limiting factor for the organic farms because the farmer does not buy expensive inputs. With more capital, conventional farmers are able to cultivate more land and increase their income.

For the labour sensitivity analysis, the simulations show that in the conventional farm an increase of one unit of labour in May and July will increase the gross margin respectively by 545CFAF and 23F CFAF. In the organic farm an increase of one unit of labour in May increases the gross margin by 236CFAFF. When we relax the rotation constraint which consists of dividing the field in portions of land (maximum 0.6 ha in the conventional farm and 0.4 in the organic farm) to allow farmers to grow more diverse crops, we found that it will lead to a specialization in one type of crop in both farming systems (green pepper which is the most profitable). The annual gross margin is also higher compared to the baseline scenario, 14,705,080 FCFAF in the conventional farm and 12,002,350 FCFAF in the organic farm. This seems to be the best situation for the two farms economically, but it far from the reality. In fact, in the study area farmers are practicing mixedfarming by growing many types of crops on the same farm. This is to help them avoid losses due to non-existence of conservation units (in case they are not able to sell all in the short term) and a local market for organic crops.

Relaxing the rotation constraint to allow the growth of one or two crops at most and enjoy a higher income would be more rational, but because farmers take into account production risks in their decision this would not be an option for farmers in the study area. Unless actions are taken to provide them with processing factories, farmers in the Niayes region will divide their land in small portions so that they can grow a variety of crops which enable consumers to enjoy the availability of fresh vegetables throughout the year. 
Citation: Amadou Binta BA, Barbier B (2015) Economic and Environmental Performances of Organic Farming System Compared to Conventional Farming System: A Case Farm Model to Simulate the Horticultural Sector of the Niayes Region in Senegal. J Horticulture 2: 152. doi:10.4172/2376-0354.1000152

Page 9 of 10

\section{Conclusion}

Our research has shown that the conventional farming system is economically more profitable than organic farming in the horticultural sector of the Niayes region in Senegal. This is mainly explained by the lower yield of the organic system and the thinness of the local market for organic food. Whereas, the equivalent carbon emission of organic horticulture is much lower than conventional horticulture. To promote organic horticulture, producers' organizations, NGO's and the government should increase awareness of the consumers. Also the necessary is the creation of a market for organic products in the region in order to ensure the sustainability of the sector and to provide consumers with healthy vegetables. Sensitive analysis also suggests that the government should help farmers to get more access to capital.

Our study suggests that, through appropriate investment in agroecological research to improve organic management and the establishment of a local market for organic crops, organic farming can be a very competitive alternative to conventional farming when it comes to healthy food production with less environmental impact. However, further studies are needed on components of sustainable intensification to see which system of production is more profitable for farmers of the Niayes region, but also beneficial for the environment, and at regional and even national levels. Moreover, we recommend that NGO's who promote organic farming in the study area should encourage farmers to partially adopt the system in order to help them to make a balance between economic sustainability (better revenues) and environmental sustainability (less use of chemical fertilizers).

\section{Acknowledgement}

The authors wish to thank WASCAL (West African Science Service Center on Climate Change and Adapted Land Use) and ZEF-Bonn (Center for Development Research) for funding. They also wish to thank the supervisors (Prof. Ahmadou Aly Mbaye and Prof. Joachim Von Braun) of the corresponding author for their guidance and recommendations. We gratefully acknowledge the help of Dr. Marc Mueller, Dr. Detlef Virchow and Cait Kinsella in correcting the draft of this piece of work.

\section{References}

1. Adams RM, Hurd BH, Lenhart S, Leary N (1998) Effects of Global Climate Change on Agriculture: An Interpretative Review. Clim Res 11: 19-30.

2. IFOAM (2009) The Contribution of Organic Agriculture to Climate Change Adaptation in Africa. International Federation of Organic Agriculture Movements (IFOAM-2009).

3. IPCC (2007) Climate Change 2007: Impact, Adaptation and Vulnerability. Contribution of Working Group II to the Fourth Assessment Report of the Intergovernmental Panel on Climate Change. ML Parry, OF Canziani, JP Palutikof, PJ van der Linden and C.E.

4. Mbenka RN (2012) Organic Farming as a Strategy for Climate Change Adaptation and Mitigation in Sub-Saharan Africa: Implications for Policy. Journal of Agricultural Extension 16.

5. Uprety DC, Dhar S, Hongmin D, Kimball BA, Garg A, et al. (2012) Technologies for Climate Change Mitigation-Agriculture sector-. TNA Guidebook series, UNEP Ris?, Centre on Energy, Climate Change Sustainable Development.

6. FAO (2008) Climate Change Adaptation and Mitigation in the Food and Agriculture Sector: A Technical Background Document. Climate Change, Energy and Food, Rome.

7. FAO (2011) Organic Agriculture and Climate Change Mitigation: A Report of the Round Table on Organic Agriculture and Climate Change.
Food and Agriculture Organization of the United Nations, Natural Resources Management and Environmental Department, Rome-Italy.

8. Middelberg SL (2013) Sustainable Agriculture: A Review of Challenges Facing the South African Agricultural Sector. J Hum Ecol 42: 163-169.

9. Godfray HC, Beddington JR, Crute IR, Haddad L, Lawrence D, et al. (2010) Food security: the challenge of feeding 9 billion people. Science 327: 812-818.

10. Foley JA, Ramankutty N, Brauman KA, Cassidy ES, Gerber JS, et al. (2011) Solutions for a cultivated planet. Nature 478: 337-342.

11. Pretty J, Toulmin C, Williams S (2011) Sustainable Intensification in African Agriculture. International Journal of Agricultural Sustainability.

12. Parmentier S (2014) Scaling up Agro-ecological Approaches: What, Why and How? Oxfam-Solidarity, Belgium.

13. Seufert V, Ramankutty N, Foley JA (2012) Comparing the yields of organic and conventional agriculture. Nature 485: 229-232.

14. Ponti T de, Rijk B, van Ittersum MK (2012) The Crop Yield Gap between Organic and Conventional Agriculture. Agricultural Systems 108:1-9.

15. Gabriel D, Sait SM, Kunin WE, Benton TG (2013) Food Production vs. Biodiversity: Comparing Organic and Conventional Agriculture. Journal of Applied Ecology 50: 355-364.

16. Pretty JN (1995) Regenerating Agriculture: Policy and Practices for Sustainability and Self-Resilience. Book Review by Peter J. Atkins in International Journal of Environmental Studies 47: 297-297.

17. Reganold JP, Glover JD, Andrews PK, Hinman HR (2001) Sustainability of three apple production systems. Nature 410: 926-930.

18. Parrot N, Marsden T (2002) The Real Green Revolution: Organic and Agro-ecological Farming in the South. Greenpeace Environmental Trust, UK.

19. Wynen E (2006) 'Economic Management in Organic Agriculture'. In: Kristiansen P, Reganold J, Taji A (eds): Organic Agriculture, a Global Perspective, chapter 8 CSIRO Publishing Melbourne, p. 236.

20. Badgley C, Moghtader J, Quintero E, Zakem E, Chappell MJ, et al. (2007) Organic Agriculture and the Global Food Supply. Renewable Agriculture and Food Sytems: 22: 86-108.

21. Ndungu SK, Macharia I, Gahtu RK, Wahome RG (2013) Impact of Organic Vegetable Production System in Kiambu and Kajiado Counties of Kenya. Journal of Environmental Science and Engineering 256-266.

22. Nemes N (2009) "Comparative Analysis of Organic and Non-organic Farming Systems: A Critical Assessment of Farm Profitability". Food and Agriculture Organization of the United Nations, Natural Resources Management Environment Department.

23. Buysse J, Huylenbroeck G, Lauwers L (2007) Normative, Positive and Econometric Mathematical Programming as Tools for Incorporating of Multi-functionality in Agriculture Policy Modelling. Agriculture, Ecosystems and Environment 120: 70-80.

24. Dantzig GB (1949) Programming of Independent Activities. Math Model, Econometrica 17: 200-211.

25. Heckelei T, Witzke HP, Henrichsmeyer W (2001) Agricultural Sector Modeling and Policy Information Systems. Proceeding of the 67th EAAE Seminar, Bonn. Wissenschaftsverlag Vauk Kiel.

26. Ugwa KA, Agwu A (2012) Mathematical Modeling as a Tool for Sustainable Development in Nigeria. International Journal of Academic Research in Progressive Education and Development 1:2.

27. Langley JA, Heady EO, Olson KD (1983) The Macro Implications of a Complete Transformation of US Agricultural Production to Organic Farming Practices. Agriculture, Ecosystems and Environment 10: 323-333.

28. Mansvelt Van JD, Mulder JA (1993) European Features for Sustainable Development: A Contribution to the Dialogue. Landscape and Urban Planning 27: 67-90.

29. Stockdale EA, Lampking NH, Hovi M, Keatinge R, Lennartsson EKM, et al. (2001) Agronomic and Environmental Implications of Organic Farming Systems. Advances in Agronomy, Academic Press, 70: 261-262. 
Citation: Amadou Binta BA, Barbier B (2015) Economic and Environmental Performances of Organic Farming System Compared to Conventional Farming System: A Case Farm Model to Simulate the Horticultural Sector of the Niayes Region in Senegal. J Horticulture 2: 152. doi:10.4172/2376-0354.1000152

Page 10 of 10

30. Mahoney PR, Olson KD, Porter KM, Huggins DR, Perillo CA, et al (2004) Profitability of Organic Cropping Systems in Southwestern Minnesota. Renewable Agriculture and Food Systems 19: 35-46.

31. Tanrivermis H (2008) Comparative Economic Assessment of Conventional and Organic Hazelnut Farming in Turkey: Results of
Questionnaires from Three Years. Biological Agriculture and Horticulture 26: $235-267$

32. Delbridge TA, Coulter JA, King RP, Lazarus W (2011) Economic Performance of Long- term Organc and Conventional Cropping Systems in Minnesota. Agronomy Journal 103: 1372-1382. 